\title{
Distribution of Organic Carbon, Nitrogen and Phosphorus in Water-Stable Aggregates of Onwu Floodplain Soils, Nigeria.
}

\author{
P. O. Ogbaji ${ }^{1}$, Li Jianmin ${ }^{1}$, A. E. Eneji ${ }^{2} *$ \\ ${ }^{I}$ College of Agronomy and Biotechnology, China Agricultural University of Beijing China \\ ${ }^{2}$ Department of Soil Science, Faculty of Agriculture, University of Calabar, Cross River State, Nigeria
}

\begin{abstract}
Soil pedons studied of Onwu floodplain in Cross River State, Nigeria for physic-chemical properties of whole-soil and water-stable aggregates $4.75-2.00,2.00-1.00,1.00-0.50,0.50-0.25$ and $<0.25 \mathrm{~mm}$. Whole-soil and WSA relative distributions of organic carbon, total nitrogen and available phosphorus were evaluated under two tillage systems CT and NT. Nearness to the river affected the SOC distribution within the WSA with high values of SOC obtained from WSA $4.75-2.00 \mathrm{~mm}$ mostly in pedons nearest to river. SOC concentrations whole-soil and aggregate $4.75-2.00 \mathrm{~mm}$ of $C T$ were $(p<0.05)$ in pedon, horizon recorded ( $p$ $<0.01)$ whole-soil and other aggregates sizes except aggregate $0.50-0.25 \mathrm{~mm}$, interaction $(p<0.05)$. Under NT whole-soil, $4.75-2.00$ and $1.00-0.50 \mathrm{~mm}$ aggregates were ( $p<0.05$ ) among pedons, while wholesoil and $4.75-2.00 \mathrm{~mm}$ aggregate were $(p<0.01)$ among horizons, while other aggregates organic carbon were $(p<0.05)$. Total nitrogen concentration of whole-soil was $(p<0.05)$ among pedons while horizon whole-soil and other aggregates were $(p<0.01)$, except $<0.25 \mathrm{~mm}$ aggregate with $(p<0.05)$ of CT. Total nitrogen concentration in aggregates $4.75-2.00$ and $0.50-0.25 \mathrm{~mm}$ were $(p<0.05)$ of NT among pedons, horizons whole-soil and other aggregates were $(p<0.01)$ except $0.50-0.25 \mathrm{~mm}$ aggregate, interaction $(p<$ 0.05 ) for $4.75-2.00$ and $<0.25 \mathrm{~mm}$ aggregates. Higher C/N ratio of whole-soils over the WSA classes implied active mineralization of soil organic matter in aggregates. Available Phosphorus content of both whole-soil and five WSA classes is low reflecting the low phosphorus contents of the parent materials, fixation and redistribution of phosphorus by erosion and flood.
\end{abstract}

Keywords: Soil organic carbon, water-stable aggregates, floodplain, carbon-nitrogen ratio, soil pedons.

\section{Introduction}

In West Africa sub-region, the common agricultural practice system is basically shifting cultivation involves slashing and burning with its negative consequences effects of nutrients losses (Ahn, 1979). Cultivation of soils results in the disruption of soil aggregates and loss of soil organic matter compared with no-tillage soils ( van Veen and Paul, 1981; Tisdall and Oades, 1982; Elliot, 1986; Kay, 1990 ). Conventional tillage system result in mixing of soil pedon and burial residues of crop thus moderate temperature and water in buried residues thereby enhancing decomposition and transformations ( Blevins et al., 1984; Beare et al., 1992) The role of water-stable aggregates, soil organic carbon, nitrogen and phosphorus in plant nutrition is enormous. Under no-till practices crop residues are left on soil surface as mulch. Several studies have shown that this practices improve soil aggregation thus reduce soil organic matter and nutrients losses that result from tillage ( Havlin et al., 1990; Carter., 1992; Weill et., 1989 ).Loamy sand floodplain soils of Onwu in northern senatorial district of cross river state, Nigeria are characterized by high dispersibility, a factor that enhances susceptibility of tilled soils to aggregate disruption, surface crusting, poor infiltration and erosion ( Miller and Baharuddin, 1986 ). In tropical climate, these factors can contribute to rapid losses of soil organic matter and a decline in the productivity of agricultural soils ( Gidden, 1957; Bruce et al., 1990b; Sanchez et al., 1989 ). Although several studies have investigated the relationships between whole-soil organic matter and water-stable aggregates ( Chaney and Swift, 1984; Kemper and Koch, 1996; Angers et al., 1992 ), but relatively few have attempted to studies soil organic carbon, total nitrogen an available phosphorus with water-stable aggregates in respect of soil depth and pedogenic implications. These relationships are largely unknown for Onwu floodplain soils. Therefore, better understanding of these relationships is crucial for management of arable land aggregation ( Tisdall and Oades, 1982 ) to wide range of soils. The objective of this study was to examine how differences in water-stable aggregates influence soil organic carbon, total nitrogen and available phosphorus distribution under two tillage systems in floodplain soils.

Site Description and soils

\section{Materials And Methods}

Soils were sampled from the long-term ( $17 \mathrm{yr}$ ) $\mathrm{CT}$ and NT floodplain plots at Akraba-Itekpa of Yala LGA, cross river state, Nigeria located $\left(6^{0} 45^{\prime} 59^{\prime \prime} \mathrm{N} ; 8^{0} 38^{\prime} 55^{\prime \prime} \mathrm{E}\right.$ ), (Fig 1). The area is within the southern Guinea Savanna Ecological Zone of Nigeria. The mean annual precipitation of the area is $1750-2000 \mathrm{~mm}$, mean annual 
temperature of $27-28^{\circ} \mathrm{C}$, and mean relative humidity of 50 to $60 \%$ (Ekwueme,2003). The soil at this site is well drained sandy clay loam ( sand \% 58.6 and clay $30 \%$ ) of CT and clay loam ( sand \% 34.6 and clay \% 34.0 ) poorly drained NT plots respectively. Some general physical properties are given on table 1 . The experimental total plots ( 480 ha ) with CT ( 110 ha ) and NT ( 370 ha ). The conventional tillage (CT) plots were tilled manually twice a year to plant Yam, cassava and groundnut later incorporate crop residues, weeds were control manually. Replicated samples were taken from the pedons of each tillage method using free survey technique to choose sites representative of different soil units on the Onwu floodplain. Total of 6 pedons were dug 3 for each soil unit (fig.2). Soils were stored field moist ( $3^{\circ} \mathrm{C}$ ) in crush-resistant air-tight containers prior to analysis not later than two week. All samples were pre-sieved $(2.0 \mathrm{~mm})$ prior to wet sieving to remove stones and crop stubble and to initial dimension of the aggregates for analysis.

Area of study: Field observation of auger soil samples was done at a distance of $200 \mathrm{~m}$ apart. The soil samples were labeled, air dried, passed through $2.00 \mathrm{~mm}$ sieve and taken as whole soil. Total of eighteen pedons were dug in triplicates $(3 \times 3)$ and $(3 \times 3)$ in $(\mathrm{CT})$ and $(\mathrm{NT})$ respectively (fig. 2$)$.

\section{Aggregates Distribution}

Kemper and Rosenau method (1986) was used to separate water-stable aggregates, fifty grams (50g) of the $<4.75 \mathrm{~mm}$ air dried soil were put in the topmost of the four sieves set $2.00,1.00,0.50$, and $<0.25 \mathrm{~mm}$, presoaked in de-ionized water for thirty minutes. Thereafter, nest of the sieves and its contents were oscillated vertically (wet sieved) and to allow for complete recovery of all particle fractions from individual samples. After wet sieved, the resistant soil materials on each sieve surface and the unstable $(<0.25 \mathrm{~mm})$ aggregates were transferred into clean beakers, dried gently in the oven at $40^{\circ} \mathrm{C}$ for $48 \mathrm{hrs}$, weighed and determination for organic carbon, total Nitrogen and available phosphorus in the aggregates class. The percentage ratio of each aggregates in each sieve surface represented the water-stable aggregate sizes of each of the five classes after Correction for sand content. The mean weight diameter (MWD) of the water-stable aggregates was calculated as:

$$
\text { MWD }=\sum_{i}^{\mathbf{n}} \overline{\text { xi wi }}
$$

Where $\bar{X}_{i}$ as mean of the remained aggregates diameter on the $i^{\text {th }}$ sieve size and $w i$ as ratio of the remained aggregates weight on the sieve to the sample total weight and $\mathrm{n}$ represented as the number of sieves for separation. Higher mean weight diameter values imply higher proportions of macro-aggregates in the samples. Particle size distribution of $<2.00 \mathrm{~mm}$ fractions was measured according to Gee and Bauder (1986). The total carbon in whole soil and water-stable aggregates was determined by the Walkley and Black method as modified by Allison (1965). Total nitrogen in the whole soil and water-stable aggregates determined by micro kjeldahl method (Bremner, 1965) and available phosphorus by Bray II method( Bray and krutz 1945). Data for aggregates size distribution of soil organic carbon, total nitrogen and available phosphorus were analyzed using stat- view soft ware package with treatment as main plot, aggregate-size class as split and pedons soil depth as the replicated measured variable.

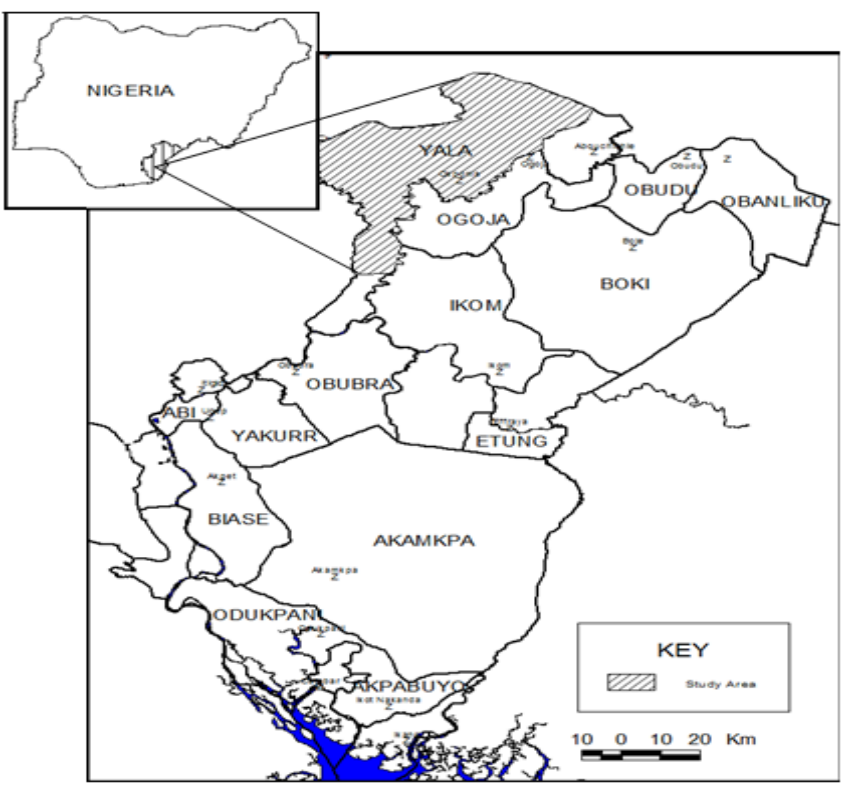

Fig 1: Map of Cross River State and Yala Local Government Area. 


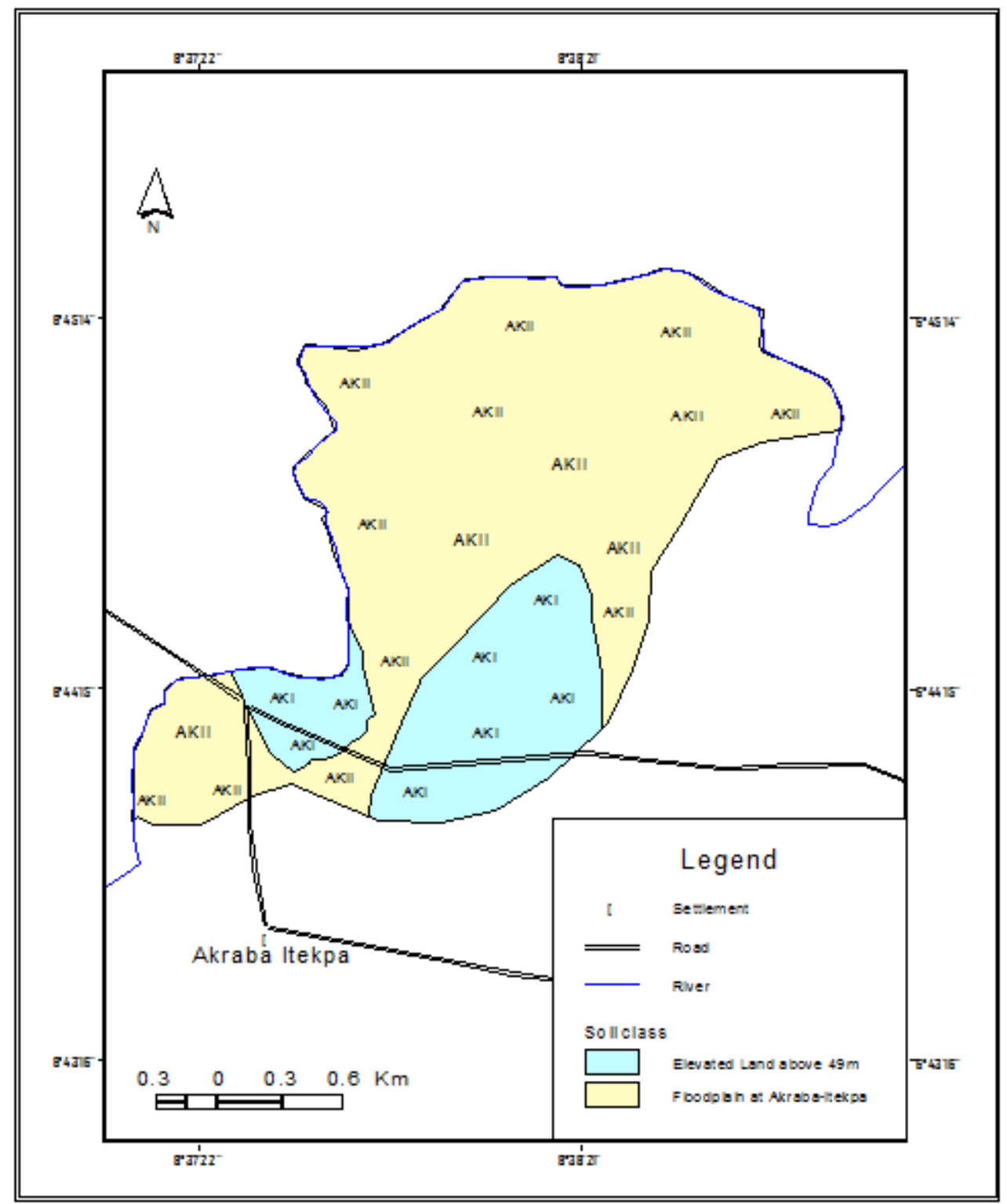

Fig. 2: Soil Map of the Onwu floodplain soils studied in Yala Local Government Area, Cross River State, Nigeria

\section{Results}

Table 1 presents the major characteristics of the soils that are medium to fine textured with more silt and fine sand in the profiles closest to the river. The distribution of sand, clay fractions percentage and meanweight diameter ( MWD ) in soil depth was significantly influenced by tillage practice, aggregate size and soil depth with significant $(\mathrm{p}<0.01)$ for sand, clay fractions and MWD of $(\mathrm{p}<0.05)$ among horizons of ( CT ). While clay and MWD were $(\mathrm{p}<0.05)$ and $(\mathrm{P}<0.01)$ in pedons and among horizons of ( NT ). Soils under NT and CT were generally sandy and acidic which could be attributed to coastal plain sands. The pedogenesis of these soils was influenced by fluvial and anthropogenic activities.

Table 1: Summary of Analysis of Variance on Sand, Silt and Clay Percent of CT and NT

\begin{tabular}{|c|c|c|c|c|c|}
\hline \multicolumn{6}{|l|}{ Source Variation } \\
\hline Location & \multicolumn{5}{|c|}{ Mean Square; F- ratios } \\
\hline CT & df & Sand (\%) & Silt (\%) & Clay $(\%)$ & MWD(mm) \\
\hline Pendon & 2 & $0.6718^{\mathrm{NS}}$ & $0.9954^{\mathrm{NS}}$ & $0.6565^{\mathrm{NS}}$ & $0.0633^{\mathrm{NS}}$ \\
\hline Horizon & 3 & $<0.0001 * *$ & $0.0140^{\mathrm{NS}}$ & $<0.0001 * *$ & $0.0012 *$ \\
\hline \multicolumn{6}{|l|}{ Interaction } \\
\hline Pedon*Horizon & & $0.7155^{\mathrm{NS}}$ & $0.5153^{\mathrm{NS}}$ & $0.3299^{\mathrm{NS}}$ & $0.9652^{\mathrm{NS}}$ \\
\hline \multicolumn{6}{|l|}{ NT } \\
\hline Pendon & 2 & $0.2576^{\mathrm{NS}}$ & $0.1134^{\mathrm{NS}}$ & $0.0066^{*}$ & $<0.0001 * *$ \\
\hline
\end{tabular}


Distribution of Organic Carbon, Nitrogen and Phosphorus in Water-Stable Aggregates of Onwu ..

\begin{tabular}{|l|l|l|l|l|l|}
\hline Horizon & 3 & $0.0656^{\mathrm{NS}}$ & $0.6147^{\mathrm{NS}}$ & $0.0286^{*}$ & $<0.0001^{* *}$ \\
\hline Interaction & & $0.9999^{\mathrm{NS}}$ & $0.979^{\mathrm{NS}}$ & $0.9640^{\mathrm{NS}}$ & $0.5052^{\mathrm{NS}}$ \\
\hline Pedon*Horizon & &
\end{tabular}

$*=$ significant $(\mathrm{P}<0.05) ; * *=$ highly significant $(\mathrm{P}<0.01)^{\mathrm{NS}}=$ not significant.

MWD = Mean weight Diameter, CT= conventional tillage, NT= no-till

Water-stable aggregates and mean-weight diameter

In all the pedons water-stable aggregate $4.75-2.00 \mathrm{~mm}$ dominated the other aggregate classes on the topsoil except pedon 6 . The WSA class $1.00-0.50 \mathrm{~mm}$ dominated other water-stable aggregates in all pedons as of result seasonal flooding. The (CT) area classified as typic Kandiudult, coarse loamy siliceous iso-hyperthermic while the (NT) plot classified as Fluvaquentic Humaquent, fine clayey siliceous iso-hyperthermic ( USDA ).

Table 2: Summary of Analysis of Variance of Concentration of SOC in Water Stable Aggregate

\begin{tabular}{|c|c|c|c|c|c|c|c|}
\hline \multicolumn{8}{|l|}{ Source Variation } \\
\hline Location & \multicolumn{7}{|c|}{ Mean Square; F- ratios } \\
\hline CT & df & Whole soil & $4.75-2.00$ & $2.00-1.00$ & $1.00-0.50$ & $0.50-0.25$ & $<0.25$ \\
\hline Pedon & 2 & $0.0013 *$ & $0.0412 *$ & $0.2430^{\mathrm{NS}}$ & $0.9370^{\mathrm{NS}}$ & $0.6648^{\mathrm{NS}}$ & $0.6386^{\mathrm{NS}}$ \\
\hline Horizon & 3 & $<0.0001 * *$ & $<0.0001 * *$ & $<0.0001 * *$ & $<0.0001 * *$ & $0.0005^{*}$ & $<0.0001 * *$ \\
\hline \multicolumn{8}{|l|}{ Interaction } \\
\hline Pedon*Horizon & & $0.0250^{*}$ & $0.2574^{\mathrm{NS}}$ & $0.6103^{\mathrm{NS}}$ & $0.9370^{\mathrm{NS}}$ & $0.9313^{\mathrm{NS}}$ & $0.4522^{\mathrm{NS}}$ \\
\hline \multicolumn{8}{|l|}{ NT } \\
\hline Pendon & 2 & $0.0586^{*}$ & $0.0073^{*}$ & $0.2016^{\mathrm{NS}}$ & $0.0205^{*}$ & $0.6783^{\mathrm{NS}}$ & $0.7115^{\mathrm{NS}}$ \\
\hline Horizon & 3 & $<0.0001 * *$ & $<0.0001^{* * *}$ & $0.0004^{*}$ & $0.0009 *$ & $0.0018^{*}$ & $0.0006^{*}$ \\
\hline \multicolumn{8}{|l|}{ Interaction } \\
\hline Pedon*Horizon & & $0.1621^{\mathrm{NS}}$ & $0.2233^{\mathrm{NS}}$ & $0.3014^{\mathrm{NS}}$ & $0.3861^{\mathrm{NS}}$ & $0.4679^{\mathrm{NS}}$ & $0.4027^{\mathrm{NS}}$ \\
\hline
\end{tabular}

$*$ = significant $(\mathrm{P}<0.05), * *=$ highly significant $(\mathrm{P}<0.01),{ }^{\mathrm{NS}}=$ not significant.

Distribution of Soil Organic Carbon

Table 2 show the distribution of SOC in soils of (CT) and (NT) respectively. The concentrations of soil organic carbon in aggregate size classes were strongly influenced by the different proportions of sand in wholesoil and in each size class. In the surface soils, concentration of soil organic carbon were significantly affected by tillage, aggregate size $4.75-2.00 \mathrm{~mm}$ with $(\mathrm{p}<0.05)$ significant for whole-soil among pedons and, $(\mathrm{p}<$ $0.01)$ among horizons and their interaction $(\mathrm{p}<0.05)$ under whole-soil while aggregates $4.75-2.00 \mathrm{~mm}$ were $(\mathrm{p}<0.05)$ and $(\mathrm{p}<0.01$ )among pedons and horizons, $2.00-1.00 \mathrm{~mm}(\mathrm{p}<0.01)$ among horizons, same trend for $1.00-0.50,<0.25 \mathrm{~mm}$ and ( 0.05 ) for $0.50-0.25 \mathrm{~mm}$ of ( CT ) Table 2. In surface soils of ( NT ) soil organic carbon values were high in whole-soil, aggregates $4.75-2.00$ and $2.00-1.00 \mathrm{~mm}$ compared to wholesoil and similar aggregates of ( CT ). In whole-soil organic carbon showed significant of ( $\mathrm{p}<0.05)$ among pedons, $(\mathrm{p}<0.01)$ in horizons with their interaction $(\mathrm{p}<0.05)$. Aggregates $4.75-2.00 \mathrm{~mm}$ were $(\mathrm{p}<0.05)$ and $(\mathrm{p}<0.01)$ among pedons and horizons, aggregate $2.00-1.00 \mathrm{~mm}$ was $(\mathrm{p}<0.01)$ among horizons, similar trends exhibited for $1.00-0.50,<0.25 \mathrm{~mm}$ aggregates and $(\mathrm{p}<0.05)$ for $0.50-0.25 \mathrm{~mm}$. of $(\mathrm{CT})$. In the ( NT ) whole-soil, aggregates $4.75-2.00$ and $1.00-0.50 \mathrm{~mm}$ were $(\mathrm{p}<0.05)$ among pedons in respect of organic carbon concentration and $(\mathrm{p}<0.01)$ for whole-soil and $4.75-2.00 \mathrm{~mm}$ while other were $(\mathrm{p}<0.05)$ in horizons of NT (table 2 ). These results showed that most of the whole-soil and WSA organic carbon distribution of ( NT ) were associated with largest aggregates in top soils. These values decreased with depth in their corresponding pedons. Seasonal deposition of organic matter could be responsible for high SOC values on top soils. Also soils under NT are minimally exposed to degradation thus retained high SOC. In the surface soils of CT distribution of organic carbon were significantly affected by tillage, aggregate size and their interaction ( $\mathrm{p}<0.05$ ) significant for whole-soil. Although some differences in organic carbon content of WSA in subsurface soils were significant and similar in pattern to surface soil, the absolute differences between aggregates classes were relatively small. Within aggregate size classes, the reduction of organic carbon content with depth was much greater in NT than in CT Table 2.

\section{Soil Total Nitrogen}

Results on soil total nitrogen showed on ANOVA Summary ( table 3 ) The soil total nitrogen distribution were higher under NT when compared to that in CT. Larger water-stable aggregate classes had more STN than smaller aggregates. In soils under CT whole-soil showed $(\mathrm{p}<0.05)$ significant among pedons and highly significance differences $(\mathrm{p}<0.01)$ within horizons for whole-soil and all other aggregates except $<0.25$ mm with $(\mathrm{p}<0.05)$. Table 3 . 
Distribution of Organic Carbon, Nitrogen and Phosphorus in Water-Stable Aggregates of Onwu ..

Table 3: Summary of Analysis of Variance of Concentration of T.N in Water Stable Aggregate

\begin{tabular}{|c|c|c|c|c|c|c|c|}
\hline \multicolumn{8}{|l|}{ Source Variation } \\
\hline Location & \multicolumn{7}{|c|}{ Mean Square; F- ratios } \\
\hline CT & df & $\begin{array}{c}\text { Whole } \\
\text { soil }\end{array}$ & $4.75-2.00$ & $2.00-1.00$ & $1.00-0.50$ & $0.50-0.25$ & $<0.25$ \\
\hline Pendon & 2 & $0.0121 *$ & $0.2433^{\mathrm{NS}}$ & $0.4089^{\mathrm{NS}}$ & $0.3920^{\mathrm{NS}}$ & $0.2381^{\mathrm{NS}}$ & $0.3636^{\mathrm{NS}}$ \\
\hline Horizon & 3 & $<0.0001 * *$ & $<0.0001 * *$ & $<0.0001^{* * *}$ & $0.0003^{* * *}$ & $<0.0001^{* * *}$ & $0.0026^{*}$ \\
\hline \multicolumn{8}{|l|}{ Interaction } \\
\hline Pedon*Horizon & & $0.8192^{\mathrm{NS}}$ & $0.9251^{\mathrm{NS}}$ & $0.9493^{\mathrm{NS}}$ & $0.7588^{\mathrm{NS}}$ & $0.6895^{\mathrm{NS}}$ & $0.9723^{\mathrm{NS}}$ \\
\hline \multicolumn{8}{|l|}{ NT } \\
\hline Pendon & 2 & $0.2291^{\mathrm{NS}}$ & $0.0060^{*}$ & $0.2975^{\mathrm{NS}}$ & $0.2687^{\mathrm{NS}}$ & $0.0004 *$ & $0.1091^{\mathrm{NS}}$ \\
\hline Horizon & 3 & $<0.0001 * *$ & $<0.0001 * *$ & $<0.0001^{* *}$ & $0.0001 * *$ & $<0.0001^{* *}$ & $0.0001 * *$ \\
\hline \multicolumn{8}{|l|}{ Interaction } \\
\hline Pedon*Horizon & & $0.1726^{\mathrm{NS}}$ & $0.0220^{*}$ & $0.0968^{\mathrm{NS}}$ & $0.6087^{\mathrm{NS}}$ & $0.1294^{\mathrm{NS}}$ & $0.0314 *$ \\
\hline
\end{tabular}

$\mathrm{T} . \mathrm{N}=$ Total Nitrogen, $*=$ significant $(\mathrm{P}<0.05), * *=$ highly significant $(\mathrm{P}<0.01),{ }^{\mathrm{NS}}=$ not significant.

The distribution of soil total nitrogen in aggregates size classes were strongly influenced by the different proportions of sand in each size class, tillage and soil depth. The concentrations of soil total nitrogen in aggregates were higher in NT when compared to that of CT. Under NT total nitrogen distributions were ( $p<$ 0.05 ) significant different for aggregates $4.75-2.00$ and $0.50-0.25 \mathrm{~mm}$ among pedons while whole-soil and all WSA were $(\mathrm{p}<0.01)$ among horizons with their interactions of $(\mathrm{p}<0.05)$ for aggregates $4.75-2.00$ and $<$ $0.25 \mathrm{~mm}$ Table 3. In surface soils, concentrations of nitrogen were significantly affected by tillage, aggregates class of CT. Also frequency of disturbances and denitrification of soils under CT could have be responsible lower soil total nitrogen distributions. These results of total nitrogen concentration in aggregates showed similar pattern as organic carbon (Table 3).

Carbon-nitrogen $(\mathrm{C}: \mathrm{N})$ ratio

Table 4: Summary of Analysis of Variance of Concentration of C: N in Water Stable Aggregate

\begin{tabular}{|c|c|c|c|c|c|c|c|}
\hline \multicolumn{8}{|l|}{ Source Variation } \\
\hline Location & \multicolumn{7}{|c|}{ Mean Square; F- ratios } \\
\hline CT & df & $\begin{array}{c}\text { Whole } \\
\text { soil }\end{array}$ & $4.75-2.00$ & $2.00-1.00$ & $\begin{array}{l}1.00- \\
0.50\end{array}$ & $0.50-0.25$ & $<0.25$ \\
\hline Pendon & 2 & $0.0043 *$ & $0.8852^{\mathrm{NS}}$ & $0.4982^{\mathrm{NS}}$ & $0.3893^{\mathrm{NS}}$ & $0.2497^{\mathrm{NS}}$ & $0.3409^{\mathrm{NS}}$ \\
\hline Horizon & 3 & $<0.0001 * *$ & $0.6937^{\mathrm{NS}}$ & $0.3883^{\mathrm{NS}}$ & $0.8942^{\mathrm{NS}}$ & $0.1183^{\mathrm{NS}}$ & $0.4279^{\mathrm{NS}}$ \\
\hline \multicolumn{8}{|l|}{ Interaction } \\
\hline Pedon*Horizon & & $0.0044^{*}$ & $0.8227^{\mathrm{NS}}$ & $0.4717^{\mathrm{NS}}$ & $0.4868^{\mathrm{NS}}$ & $0.4908^{\mathrm{NS}}$ & $0.6550^{\mathrm{NS}}$ \\
\hline \multicolumn{8}{|l|}{ NT } \\
\hline Pendon & 2 & $0.1770^{\mathrm{NS}}$ & $0.2633^{\mathrm{NS}}$ & $0.0004 *$ & $0.8675^{\mathrm{NS}}$ & $0.0002 *$ & $0.3279^{\mathrm{NS}}$ \\
\hline Horizon & 3 & $0.0008^{*}$ & $0.0012 *$ & $<0.0001 * *$ & $0.0341 *$ & $<0.0001 * *$ & $0.0023 *$ \\
\hline \multicolumn{8}{|l|}{ Interaction } \\
\hline Pedon*Horizon & & $0.2944^{\mathrm{NS}}$ & $0.8723^{\mathrm{NS}}$ & $<0.0001 * *$ & $0.5163^{\mathrm{NS}}$ & $0.0005^{*}$ & $0.8412^{\mathrm{NS}}$ \\
\hline
\end{tabular}

C: $\mathrm{N}=$ Carbon: Nitrogen Ratio, $*=$ significant $(\mathrm{P}<0.05),{ }^{*} *$ highly significant $(\mathrm{P}<0.01)$, NT $=$ Not Significcant

The differences between CT and NT in whole-soils and aggregate associated organic carbon and total nitrogen were also reflected in the $\mathrm{C}$ : $\mathrm{N}$ ratios of organic carbon and aggregate associated nitrogen ( table 4 ). Higher ratios of the whole-soils $\mathrm{C}: \mathrm{N}$ for NT were observed over the WSA classes with $\mathrm{C}: \mathrm{N}$ ratios less under NT The higher $\mathrm{C}: \mathrm{N}$ ratio of whole-soils over WSA classes under NT was due to abundance raw organic matters that are less decomposed when compared with organic matters in WSA. This condition is further influenced by tillage which degrade the aggregate stability thus making soil vulnerable to serious degradation.This trend was reversed in pedons of CT which had lesser $\mathrm{C}: \mathrm{N}$ in whole-soils whereas WSA classes had higher $\mathrm{C}: \mathrm{N}$ ratios. Under $\mathrm{CT}$ whole-soil were $(\mathrm{p}<0.05$ and $\mathrm{p}<0.01)$ significant for pedons and horizons, with their interaction of $(\mathrm{p}<0.05)$, while under NT aggregates $2.00-1.00$ and $0.50-0.25$ mm were ( $\mathrm{p}<0.05)$ significant different among pedons in $\mathrm{C}: \mathrm{N}$ ratio while horizons showed significant of $(\mathrm{p}<0.05)$ for whole-soil, $4.75-2.00,1.00-0.50$ and $<0.25 \mathrm{~mm}$ and $(\mathrm{p}<0.01$ ) for $2.00-1.00,0.50-0.25 \mathrm{~mm}$ with interactions $(\mathrm{p}<0.01$ and $\mathrm{p}<0.05$ ) for $2.00-1.00$ and $0.50-0.25 \mathrm{~mm}$ table 4 . The higher $\mathrm{C}: \mathrm{N}$ ratio of the whole-soil over the water-stable classes in soil under NT implies abundance of raw organic materials that is partially decomposed. 
Distribution of Organic Carbon, Nitrogen and Phosphorus in Water-Stable Aggregates of Onwu ..

Available Phosphorus

Table 5: Summary of Analysis of Variance of Concentration of Avail. P in Water Stable Aggregate

\begin{tabular}{|c|c|c|c|c|c|c|c|}
\hline \multicolumn{8}{|l|}{ Source Variation } \\
\hline Location & \multicolumn{7}{|c|}{ Mean Square; F- ratios } \\
\hline AK 1 & df & $\begin{array}{c}\text { Whole } \\
\text { soil }\end{array}$ & $4.75-2.00$ & $2.00-1.00$ & $1.00-0.50$ & $0.50-0.25$ & $<0.25$ \\
\hline Pendon & 2 & $0.0123 *$ & $0.0003 *$ & $0.0087^{*}$ & $0.0006 *$ & $0.0006^{*}$ & $0.0436 *$ \\
\hline Horizon & 3 & $<0.0001 * *$ & $<0.0001 * *$ & $<0.0001 * *$ & $<0.0001 * *$ & $<0.0001 * *$ & $0.0005^{*}$ \\
\hline \multicolumn{8}{|l|}{ Interaction } \\
\hline Pedon*Horizon & & $0.7702^{\mathrm{NS}}$ & $0.3434^{\mathrm{NS}}$ & $0.9830^{\mathrm{NS}}$ & $0.8076^{\mathrm{NS}}$ & $0.1696^{\mathrm{NS}}$ & $0.7826^{\mathrm{NS}}$ \\
\hline \multicolumn{8}{|l|}{ AK 11} \\
\hline Pendon & 2 & $0.5157^{\mathrm{NS}}$ & $<0.0001 * *$ & $<0.0001 * *$ & $0.0029 *$ & $<0.0001 * *$ & $0.0006^{*}$ \\
\hline Horizon & 3 & $<0.0001 * *$ & $<0.0001 * *$ & $<0.0001 * *$ & $<0.0001 * *$ & $<0.0001 * *$ & $<0.0001 * *$ \\
\hline \multicolumn{8}{|l|}{ Interaction } \\
\hline Pedon*Horizon & & $0.9156^{\mathrm{NS}}$ & $0.7128^{\mathrm{NS}}$ & $0.7128^{\mathrm{NS}}$ & $0.9589^{\mathrm{NS}}$ & $0.3582^{\mathrm{NS}}$ & $0.1374^{\mathrm{NS}}$ \\
\hline
\end{tabular}

Avail. $\mathrm{P}=$ Available Phosphorus $*=(\mathrm{P}<0.05)$ significant difference, $* *=(\mathrm{P}<0.01)$ highly significance difference, ${ }^{\mathrm{NS}}=$ not significant.

Available phosphorus distributions on Table 5 showed significance differences of $(\mathrm{p}<0.05)$ in wholesoil and all aggregates sizes in pedons while horizons exhibited $(\mathrm{P}<0.01)$ highly significance differences in horizons for whole-soil and all other aggregates except $<0.25 \mathrm{~mm}$ aggregate with a significant different of $(\mathrm{p}<$ 0.05 ) in AKI ( Table 5). Under AKII pedons recorded highly significance differences $(\mathrm{p}<0.01$ ) for aggregates $4.75-2.00,2.00-1.00$ and $0.50-0.25 \mathrm{~mm}$ while other aggregates exhibited $(\mathrm{p}<0.05)$ significance differences. Horizons showed highly significance differences of $(\mathrm{P}<0.01)$ in whole-soil and all the aggregates sizes of AKII (Table 5).

\section{Discussion}

The results of this study show that SOC is important in the aggregation of larger WSA classes although there are other aggregating agents other than SOC influencing in the plots of study. Organic carbon does not influence micro-aggregate stability greatly when the values of SOC are low ( Nwadialo and Mbagwu,1991 ). The role SOC as an aggregating agent decreases in the presence of other dominating aggregating agents especially polyvalent metals and silicate clay ( Mbagwu 1989 ). Soil organic carbon correlated significantly with MWD under NT and CT implying that increase in SOC resulted in improved rate of aggregation. The resistance of aggregates to slake and periodic submerged were attributed to organic matter bonding (Piccolo,1996). According to Igwe et al., (1999) soil organic carbon significantly stabilized macro aggregates. The wide range of carbon-nitrogen ratio of whole soil over water-stable aggregates signifies abundance of raw organic matter less decomposed than in WSA. There were no significant different in phosphorus distribution in water-stable aggregates in both soil units. Soils of southern Nigeria are noted for low phosphorus content (Enwezor, 1977).

\section{Conclusion}

The soils used in this study are Inceptisols (floodplains) developed from fluvial depositions. Types of tillage practices changed the soil properties, SOC, STN and AV. P contents of the plots. SOC are associated more with larger WSA in soils of NT whereas the reverse was the case in soils of CT. Soils of NT showed narrow and stable $\mathrm{C}: \mathrm{N}$ ratio while reverse was the case in CT. The soil organic carbon contents are important in the protection of aggregation against erosion and flood. Proximity to the river affected the distribution SOC, STN and Available phosphorus.

\section{References}

[1]. Ahn, P. (1979). West African Soils. Oxford University Press. Pp. 35

[2]. Allison, L. E. (1965). Organic carbon In Black, C. A. (Eds). Methods of Soil Analysis. Part 2. Amer, Soc. Agron, 9pp.1367-1378.

[3]. Angers, D. A.,A. Pesant, and J. Vigneux. ( 1992 ). Eaely cropping-induced changes in soil aggregation, organic matter, and microbial biomass. Soil Sci Soc. Am. J. $56: 115-119$.

[4]. Beare, M. H., R, W. Parmelee, P. F. Hendrix, W. Cheng, D.C. Coleman, and D.A. Crossley, Jr, ( 1992 ) Microbial and fauna interaction and effects on litter nitrogen and decomposition in agroecosystem. Ecol. Monogr, 62: 569 - 591.

[5]. Blevins, R. L, M. S. Smith, and G. W. Thomas ( 1984 ). Changes in soil properties under no-tillage. P. 190 - 230. In R. E. Philip and S .H. Philips (ed) No-tillage agriculture: Principles and practices.Van Nostrand Reinhold,New York.

[6]. Bruce, R. R., G.W.Langdale and L. T. West (1990b ). Modification of soil characteristics of degraded soil surfacesby biomass input and tillage affecting soil water regime. P. 4 - 9. In Trans. Intl. Congr. Soil Sci. 14 ${ }^{\text {th }}$,Kyoto, Japan. $12-18$ aug, 1990. Vol. 6. Wageningen, the Netherlands.

[7]. Bray, R. H. and Kurtz, L. T. (1945).Determination of Total organic and Available forms of phosphorus in soils. Soil Scic., 59:3945.

[8]. Bremner, J. M. (1965). Total nitrogen in Black, C. A. (Eds) Methods of Soil Analysis Part 2, Amer, Soc. Agron. App 1149-1178. 
[9]. Carter, M. R. ( 1992 ). Influence of reduced tillage systems on organic matter, microbial biomass, macro-aggregate distribution and structural stability of the surface soil in a humid climate. Siol Tillage Res 23: $361-372$.

[10]. Chaney, K., and R. S. Swift ( 1984 ). The influence of organic matter on aggregate stability in some Brtish soils, J. Soil Sci. 35 : 223 -230 .

[11]. Elliot, E. T. ( 1986 ). Aggregate structure and carbon, nitrogen and phosphorus in native and cultivated soils. Soil SCI. Soc. Am. J. $50: 627-633$.

[12]. Ekwueme,B.N. (2003).The Precambrian geology and evolution of the southeastern Nigeria basement complex ,university of Calabar, press,Pp.2-6.

[13]. Enwezor, W. O. (1997). Predicting responses of phosphate application for soils of southeastern Nigeria. soil Sci. 23:111-116.

[14]. Gee, G. W. and Bauder, J. W. (1986). Particle-Size Analysis. In Klute. A (Ed). Method of Soil Analysis. Part 1. Amer. Soc Agron a: Madison . WI pp. 91-100.

[15]. Giddens, J. ( 1957 ). Rate of loss of carbon from Georgia soils. Soil Sci. Soc. Am. Proc. 21(5): $513-515$

[16]. Havlin, J. L., D. E. Kissel, L. D. Maddux, M. M. Claasen, and J. H. Long.( 1990 ). Crop rotation and tillage effects on soil organic carbon and nitrogen. Soil Sci. Soc. Am. J. 54: $448-452$.

[17]. Igwe, C. A. Akamigbo, F. O. R. and Mbagwu, J. S. C. ( 1999 ). Chemical and mineralogical properties of soils in southeastern Nigeria in relation to aggregate stability. Geoderma. 92: $111-123$.

[18]. Kay, B. D.( 1990 ).Rate of changes of soil structure under different cropping systems. Adv. Soil Sci. $12: 1-52$.

[19]. Kemper, D. W. and Rosenau, R. C. (1986). Aggregate Stability and Size distribution. In: Kluet A. (Ed). Methods of soil analysis. Part 1 ASA and SSSA. Madison. WI pp. 425-442.

[20]. Kemper, W.D., and E. J. Koch. ( 1966 ). Aggregate stability of soils from western United States and Canada. USDA-ARS Tech. Bull. 1355. U.S Gov.Print. Office, Washington, DC.

[21]. Miller, W. P., and M. K. Baharuddin. ( 1986 ). Relationship of soil dispersibility to infiltration and erosion of southeastern soils. Soil Sci. $142: 235-240$.

[22]. Mbagwu, J. S. C. (1989). Influence of cattle feeding manure on aggregate stability, plastic limit and water relations of three soils in north central Italy. Biol Waste 28, $257-269$.

[23]. Nwadialo, B. E. Mbagwu, J. S. C. ( 1991 ). An analysis of soil components active in micro-aggregate stability. Soil Technol. 4, 343 -350 .

[24]. Piccolo. A. ( 1996 ). Humus and soil conservation. In : Piccolo A. (Ed). Humic Substance in terrestrial Ecosystems.Elsevier Publishers, Amsterdam. Pp..225 - 264.

[25]. Sanchez, P. A.,C.A. Palm, L. T. Szott, E. Cuevas, and R. Lal. ( 1989 ). Organic input management in tropical agroecosystems, p. 125 - 152. In D.C. Coleman et al, (ed). Dynamics of soil organic matter in tropical ecosystems. Univ. of Hawaii Press, Honolulu.

[26]. Tisdall ,J. M., and J. M. Oades, ( 1982 ). Organic matter and water stable aggregates in soils. J. Soil Sci. 33: 141 - 161.

[27]. Van Veen,, J. A. and E. A. Paul.( 1981 ). Organic carbon dynamics in grassland soils. I. Background information and computer simulations. Can. J. Soil Sci. 61: $185-201$

[28]. Weill, A. N., C.R. De Kimpe, and E. McKyes. ( 1989 ). Effect of tillage reduction and fertilizer on soil macro- and microaggregates. Can. J. Soil Sci. 68: 489 - 500. 